\title{
Governance in Financial Management of Villages in Kepulauan Meranti Regency
}

\author{
Yendri Nazir \\ Department of Government Science, \\ Islamic University of Riau \\ Pekanbaru, Indonesia \\ yendrinazir@gmail.com
}

\begin{abstract}
The village is an area that should be of concern to the government because the village is the most closest to the government. Law No. 6 of 2014 about the village that requires the Government to transfer $10 \%$ of the budget of funds received by the district.. Thus the village Government has the opportunity to build their own territory in accordance with their priorities. The village Government should understand how to manage the budget for community welfare and in accordance with applicable law. This paper aims to understand and investigate on how governance in the financial management of villages in Kepulauan Meranti Regency. The focus in this study is the villages found in the financial management of the village. As well as looking at how existing concepts in governance rule of the Meranti Islands Regency. As for who is the head of state of the islands and the government, so that the implementation of the governance Government can run well then the Government of the village should be transparent, accountability, effectiveness, and efficiency in the use of the Village Fund.
\end{abstract}

Keywords: Governance, accountability, transparent, effective and efficient

\section{INTRODUCTION}

The paradigm of the village confirmed that the village is a suburban area and hinterland as well as much of the territory of urban areas, social conditions, economic and culture that are still lagging very far when compared to urban areas, most the economic activities of the society with a system of farming. In classic condition, Suhardjo (2008) were categorized as rural areas economic regions that carry out economic activities of the population with agriculture while urban areas categorized as regions with the economic system the community in the field of trade and services sectors.

Another classic approach used in giving a definition of the village is the approach based on the paradigm of modernization and the model dikatomi. The emergence of an industrial area with all his village considers modernization as a representation of the traditional communities and urban areas are considered as a representation of the modern society.
Model dikatomi the other is solidarity among the Group of primary organic cons Suhardjo secondary group (2008).

The village is an area that is considered the most lagged and most underdeveloped Wasistiono (2007) it is evidenced by the Government's lack of attention to the development of the village there are even villages only considered the political land tender for politicians especially when political, after entering the year it was forgotten.

The emergence of law number 6 year 2014 of the village into a fresh wind for the construction of the village that existed in Indonesia but it also makes the village seems to elicit a's dilemma because apparatus in the village should be able to set up and manage the finances of the village with good, if it is not above begging then reasonable only if there is ahead of the village is designated as a suspect because the village chief thought that the village Fund is money her personally so that activities that they do to the construction of the village report made in accordance with her wishes not be made based on the existing rules of the game.

In this paper the author would like to see the theoretical aspects of governance as a concrete step for the Government of the village to organize well his village, associated with the financial management of the village because the village was considered the domain of finance that is most prone to the occurrence the village of budget deviation focuses on cases in Kepulauan Meranti Regency is part of. Due consideration in the part of the has been established as a village chief two suspects because it has been proven do budget deviation village.

\section{SCOPE OF QUESTION}

The urgency that exists in this study wanted to see how the Government of a village able to manage and organize the finances of the village well because there are still many villages are there in Indonesia has not been able to be transparent, accountability and effective and efficient in manage the finances of the existing villages so in this paper will explain the terms "How can governance in financial management case study village in the Kepulauan Meranti Regency? 


\section{DISCUSSION}

The concept of governance was originally developed in 1990 was marked by the presence of viewpoints (point of view) that are new to the role of government in carrying out the system of Government. Because so many have the assumption that the role of Government or ruler so great against policies that cater to the community so that the absence of and space for the community to thrive. As well as any other presumptions that the Government seems to know and understand what is required by the community, so that so many policies made without listening to input and aspirations of society so that it is top down and the public can only accept so that it resulted in the declining community support to Governments (Budiati, 2014:36).

Understanding good governance according to Mardiasmo (1999:18) is a concept-oriented approach to the development of the public sector by good governance. Further, according to the World Bank quoted Wahab (2002:34) mentions the good governance is a concept in the management of the construction of a solid and responsible in line with democracy and an efficient market, the avoidance of incorrect allocation and investment are scarce and corruption prevention both in political and administrative, budgetary discipline and the running of the creation of the legal and political framework for the growth of entrepreneurial activity. Besides the World Bank also equalize good governance as synergistic and constructive relations between the State and the public sector, Effendi (1996:47).

Transparency (transparency) is the openness of the process of the formulation of public policies for the Community (open to public participation). All national affairs in the form of public policy, both with regard to the public service as well as development in the region must be known to the public. (Yuswanto, 2003).

Efficiency relates to the financial savings, while effectiveness with regard to the accuracy of the ways used to solve the problem (Handoko, 1998:23). This principle ensures in this service to the community by using available resources optimally and responsible. Community service should give priority to the satisfaction of the community, and supported the mechanisms of oversight and budget a rational and transparent. Institutions engaged in the public service must inform about the costs and types of Ministry. To create the efficiencies of modern management techniques must be used for the administration of the need to have decentralized public service authority to the level the village. The basic instrument of efficiency and effectiveness is the political commitment while supporting instrument is an appropriate governance structure the interests of community service, the existence of standards and performance indicators to assess the effectiveness of the the Ministry of finance, bookkeeping that allows him a unit cost, and the existence of a survey-survey of consumer satisfaction.

Accountability is the ability to account for all actions and policies that have been taken (Mardiasmo, 2001:251). This principle contains the meaning of increasing the accountability of decision-makers in all areas that concern the interests of the wider community. The entire policymakers at all levels must understand the policies that are taken must be accounted to the community. To measure performance objectively need for clear indicators. Surveillance systems need to be strengthened and audit results must be published, and if there is an error should be sanctioned. The basic instrument of accountability is the existing legislation, with the commitment of political will as well as accountability mechanisms accountability, while supporting instruments are the guidelines of conduct and monitoring system the organizers of government performance and surveillance system with clear and definite sanctions.

In specific in this paper the author would like to see the concept of governance Jeff and Shah (1998) that has been described with details of each indicator in the governance aspects of transparency, especially seeing the accountability aspect and aspect effectiveness and efficiency in the management of the finances of the village case studies in the Kepulauan Meranti Regency.

\section{A. Dimensions Transparent}

Transparency is an important aspect in the implementation of the Government of the village mainly on the financial management of the village because a transparent governance will make the villagers believe his administration and finances of the village is When government sensitive village is not considered transparent then the confidence of the community against the Government of the village will be reduced.

Transparency is also considered as the openness and availability of data and information to the public that can be accessed in accordance with the rules of the game. As well as in transparency also providing clarity for the public in General to know the process of drafting, implementation, and output that will be achieved in any policies that will be made by the Government of the village.

The Government of the village needs to prepare a clear policy so that the villagers can access the information and the basic instrument of transparency is the rule that guarantees the right of villagers to obtain information, as well as instrument her supporters is a database and the means of information and communication that exists in the Organization of the Government of the village.

Transparency is openness overall actions and policies taken by the Government (Notodisoerjo, 2002:129). The principle of transparency creates a reciprocal trust between the Government and the public through the provision of information and ensure the ease in obtaining accurate information and adequate. Information is an important community need to participate in the management of the area. With regard to these local governments need to proactively provide information on policies and services that they provide to the community. 
According to Jeff and Shah (1998:68) indicators that can be used to measure transparency, i.e. the increase of the insights and knowledge society against the conduct of the Government. Increasing public confidence towards the Government, increasing its number of communities participating in the development of its territory and reduced to the breach of regulations.

The management of finance village which is conducted by the Government covered villages in Kepulauan Meranti Regency is a fact which showed weak understanding and knowledge that is owned by the Government of the village itself, especially in It reported the use of village Fund liability. Thus the Attorney set two Kepulauan Meranti Regency village chief as a suspect.

Based on the investigation conducted by the Polres Kepulauan Meranti Regency with engage team investigators from the Agency Financial Examiner province (BPKP) revealed two village chief suspected of corruption against the village Fund i.e. head the Tanjung Madang Village and head The Citra Damai Village. It is proven in an empiric village when the Government is not open to the public in the use of the budget of the village it will be going on corruption and misuse of the budget there.

Supposed to be in the good governance of the Government of the village should be more open to the public in the village and more concrete information in the use of that good village budget for construction of the village as well as to the activities of other villages.

Of the existing cases of theoretical governance particularly in the aspect of transparency expressed by Jeff and Shah (1998) the causes of the occurrence of abuse budget villages in Kepulauan Meranti Regency is not ever village government so public confidence to the Government on the wane and the communities that participated in the construction of villages also reduced due to the government the appropriate village closed to them, especially in terms of the use of the village budget they don't know where the direction of the use of the budget of the village.

To realize the accountability of Government towards the public then the one thing that must be done is to use the principle of openness. The transparency of the conduct of the village Government has important meaning where the public is given the opportunity to know the policies that will and have been taken by the Government of the village. Even with the transparency of the conduct of the government village community can give feedback or outcomes against the policies that have been taken by the Government.

This means that transparency in the conduct of the Government of the village can provide a very significant meaning in addition to one of the existence of government accountability to the people, except it also can create the Government the village is good or good governance Tahir (2011). And can also reduce the practice of collusion, corruption, and nepotism $(\mathrm{KKN})$. This is the key why transparency is so important. Because it is considered still fresh in our memory that one becomes the question of the end of the new order was the outbreak of cases of corruption and as one of the things that can bring in and gives a space for this activity is the management a Government that is not transparent to the public.

More about transparency is the main value of the system of Government. The main activity the Government should context is believed to be based on transparency. There is the strength of the public demanding transparency. In fact, there is a relation between the acceleration and the effect on the private organize as ever-increasing population requires society demands of society against the Government will be more powerful.

\section{B. Dimensions of Accountability}

Accountability is a standard size that is used to view the conformity between a program made by the Government of the village with its realization and output is also tipped to increase the trust of villagers to the Government of the village.

Public accountability is a measure or standard that indicates how large the compliance level of organization of drafting public policies with legal regulations and legislation that apply to the organization concerned. Yuswanto (2003). The sense of responsibility is an absolute requirement for the application of good governance, because as according to Alhadist, that "every human being is a leader and will be subject to accountability". Accountability was reported not only to the public but reportedly also to God Almighty.

In line with the foregoing Mahmudi explained that accountability is the obligation of the agent (the Government) to manage resources, report and disclose all activities and activities related to the use of public resources to the giver of the mandate (of the community).

The village government as an institution that is authorized for the management of resources in the village he should must be accountable to the people so that people know the obligations undertaken by the Government to serve and facilitate the community has a right to know information about the use of available finance in accordance with the request of the Government.

Basically, the responsibility the Government does not only to a higher government but also got to see and to the community as stakeholders that are closer to the village government but like the fact that the Government of the village just afraid to institution higher than the villagers.

According to Jeff and Shah (1998:70) indicators that can be used to measure accountability, i.e. increasing the confidence and satisfaction of society against the Government, growing public awareness, increasing representativeness based on the option and the interests of the community, and reduced cases of KKN. 
See examples of cases that occur in the Kepualauan Meranti Regency described the unaccountability of his Government officials to the village people. Because of the absence of present and report on any follow-up activities are mainly in the financial administration of the village since accountability is still considered the terminology from the standpoint of the control action on the achievement of the objectives.

More Mardiasmo (2006) split into two existing accountability level i.e. accountability vertical and horizontal accountability. Accountability in financial management accountability is the vertical village to higher authority e.g. to the Regent through the local head. The Government of the village of Regency Kepualaun Meranti Regency did it with timely accountability while granting horizontally report information on activities and financial performance of the Government to the parties concerned with the report.

Then Mardiasmo (2006) also offers a new categorization he termed directly accountability and indirect accountability. Accountability refers to the direct accountability of the parties external such as civil society, the consumer or client groups directly related to accountability while accountability through a chain of these commands carried a particular vertical.

Accountability is a form of accountability for the decision makers (the village government) because of every action and behavior. It also meant accountability as the obligation to explain the basis of the justification of an action or behavior. Because it is an obligation by the Government to paint be responsible report to the Community budget in order to make use of the increasing trust of the community to the Government of the village

\section{The dimensions of effectiveness and efficiency}

Effectiveness and efficiency in the management of the finances of the village here Sepik and successfully, the effectiveness is measured with the parameters of the products can reach the magnitude of the interests of various groups. Whereas efficient can be measured with the rationalist to meet the needs that exist in the institution. Where effectiveness and efficiency in the process of education, will be able to provide a satisfactory quality.

According to Jeff and Shah (1998:71) indicators that can be used to measure the efficiency and effectiveness, i.e.:

\section{1) Efficiency:}

The increasing prosperity and the added value of community service, reduced spending irregularities, reduced operational costs of service and get the ISO Services. Doing privatization of community service.

2) Effectiveness:

Increasing the input of the community against irregularities (leakage, waste, abuse of authority, and others) through the mass media and decreased deviation.
According to the idea has been said by Jeff and Shah (1998) the efficiency is an effort that must be made by the Government of the village remember if it is not done then it will happen so that excessive use of the budget against the policy created by the Government of the village will not be right on target, then it will happen a waste of budget and budget lapses occurred will be carried out by the Government of the village.

In the context of the efficiency of the governance of villages in Kepulauan Meranti Regency is not transparent to the community so that the community could not provide a response to the village government let alone give criticism against abuse of authority perpetrated by the village chief Cape Madang and Peaceful image of a village chief.

The head of the village of Tanjung Madang and the Citra Damai Village is considered taking action against the use of Budget irregularities do village Fund which he promoted them as involved by Polres Kepulauan Meranti Regency. Both the head of the village had already been dismissed by the Kepualauan Meranti Regency and are undergoing legal process.

But the top of the village Fund Budget irregularities conducted by the head of the village before it imposes to not be melted by County Government budget funds is part of the village of Islands the village of Tanjung Madang and the head Citra Damai of the village's image of peace for the fiscal the year 2016 year 2017 given report has not been made clear by village authorities.

So from existing studies then the Government must provide a proper alternative solution and so reduced the number of village chief who deals with law enforcement authorities related to the irregularities of the use of the budget. The author's solution offering is any village chief must be accompanied by a professional in the field of financial accounting of the village, not an escort of the village who do not understand the financial governance with the village and every use of an existing budget There has to be watched so that between the program being the village with which they never achieved in accordance with the facts. Sometimes corruption is not the village budget was done intentionally by the Government of the village but his policy or wrong decisions were taken can be detrimental to the financial village.

\section{CONCLUSION}

Based on the previous explanation in both theoretical aspects and empirical aspects regarding governance in financial management of villages in Kepulauan Meranti Regency is part of then can be drawn a conclusion that in the aspect of transparency, accountability, effectiveness, and efficiency are not done properly resulting in so vulnerable use of budget funds irregularities occurred village by village government. The Government should also be well guarded against the use of the budget billions of rupiah as well as give an affirmation to the head of the village do not get State 
aggrieved over the policies that they will be doing in his village.

\section{References}

[1] Suhardjo A.J, dkk. Geografi Perdesaan, Sebuah Antropologi, Yogyakarta; IdeAs Media, 2008.

[2] Wasistiono Sadu dan Irwan Tahir, Prosfek Pengembangan Desa; Fokus Media, Jakarta, 2007

[3] Budiati, Lilin, 2014. Good Governance Dalam Pengelolaan Lingkungan Hidup, Ghalia Indonesia; Bogor.

[4] Effendi, Sofian. 2005. Membangun Budaya Birokrasi Untuk Good Governance.

[5] Mardiasmo, Perpajakan, Edisi 4. Yogyakarta, Penerbit Andi, 1999.
[6] Handoko, Manajemen, BPFE Yogyakarta, Yogyakarta, 1999.

[7] Huther, Jeff and Anwar Shah. A Simple Measure of Good Governance And Its Aplication to the Debate on The Appropriate Level of Fiscal Decentralization. World Bank Policy Research Paper Series No. 1894, March 1998, Washington, DC, 1998.

[8] Notodisoerjo, R. Soegondo. Hukum Notariat di Indonesia (Suatu Penjelasan). Jakarta: PT. Grafindo. 1993.

[9] Tahir, Muh. Pengantar Metodologi Penelitian Pendidikan. Makassar: Universitas Muhammadiyah Makassar. 2011.

\section{Website-based resources}

[1] http://www.halloriau.com/read-hukrim-94713-2017-07-13-korupsidana-desa-dua-kepala-desa-di-meranti-kabur-tak-tahu-rimbanya.html 